\title{
Metabolic acclimation supports higher aluminium-induced secretion of citrate and malate in an aluminium-tolerant hybrid clone of Eucalyptus
}

Wannian $\mathrm{Li}^{1+}$, Patrick M. Finnegan ${ }^{2+}$, Qin Dai ${ }^{1+}$, Dongqiang Guo ${ }^{3+}$ and Mei Yang ${ }^{1{ }^{*+}}$ (D)

\begin{abstract}
Background: Eucalyptus is the main plantation wood species, mostly grown in aluminized acid soils. To understand the response of Eucalyptus clones to aluminum (Al) toxicity, the Al-tolerant Eucalyptus grandis $\times$ E. urophylla clone GL-9 (designated "G9") and the Al-sensitive E. urophylla clone GL-4 (designated "W4") were employed to investigate the production and secretion of citrate and malate by roots.

Results: Eucalyptus seedlings in hydroponics were exposed to the presence or absence of $4.4 \mathrm{mM} \mathrm{Al}$ at pH 4.0 for $24 \mathrm{~h}$. The protein synthesis inhibitor cycloheximide (CHM) and anion channel blocker phenylglyoxal (PG) were applied to explore possible pathways involved in organic acid secretion. The secretion of malate and citrate was earlier and greater in G9 than in W4, corresponding to less Al accumulation in G9. The concentration of Al in G9 roots peaked after $1 \mathrm{~h}$ and decreased afterwards, corresponding with a rapid induction of malate secretion. A timelag of about $6 \mathrm{~h}$ in citrate efflux in G9 was followed by robust secretion to support continuous Al-detoxification. Malate secretion alone may alleviate Al toxicity because the peaks of Al accumulation and malate secretion were simultaneous in W4, which did not secrete appreciable citrate. Enhanced activities of citrate synthase (CS) and phosphoenolpyruvate carboxylase (PEPC), and reduced activities of isocitrate dehydrogenase (IDH), aconitase (ACO) and malic enzyme (ME) were closely associated with the greater secretion of citrate in G9. PG effectively inhibited citrate and malate secretion in both Eucalyptus clones. CHM also inhibited malate and citrate secretion in G9, and citrate secretion in W4, but notably did not affect malate secretion in W4.

(Continued on next page)
\end{abstract}

\footnotetext{
*Correspondence: fjyangmei@126.com

${ }^{\dagger}$ Wannian Li, Patrick M. Finnegan, Qin Dai, Dongqiang Guo and Mei Yang contributed equally to this work.

${ }^{1}$ Guangxi Key Laboratory of Forest Ecology and Conservation, College of Forestry, Guangxi University, 100 East University Road, Nanning 530004, Guangxi, People's Republic of China

Full list of author information is available at the end of the article
}

C The Author(s). 2021 Open Access This article is licensed under a Creative Commons Attribution 4.0 International License, which permits use, sharing, adaptation, distribution and reproduction in any medium or format, as long as you give appropriate credit to the original author(s) and the source, provide a link to the Creative Commons licence, and indicate if changes were made. The images or other third party material in this article are included in the article's Creative Commons licence, unless indicated otherwise in a credit line to the material. If material is not included in the article's Creative Commons licence and your intended use is not permitted by statutory regulation or exceeds the permitted use, you will need to obtain permission directly from the copyright holder. To view a copy of this licence, visit http://creativecommons.org/licenses/by/4.0/. The Creative Commons Public Domain Dedication waiver (http://creativecommons.org/publicdomain/zero/1.0/) applies to the data made available in this article, unless otherwise stated in a credit line to the data. 


\begin{abstract}
(Continued from previous page)
Conclusions: G9 immediately secrete malate from roots, which had an initial effect on Al-detoxification, followed by time-delayed citrate secretion. Pre-existing anion channel protein first contributed to malate secretion, while synthesis of carrier protein appeared to be needed for citrate excretion. The changes of organic acid concentrations in response to Al can be achieved by enhanced CS and PEPC activities, but was supported by changes in the activities of other enzymes involved in organic acid metabolism. The above information may help to further explore genes related to Al-tolerance in Eucalyptus.
\end{abstract}

Keywords: Eucalyptus, Aluminum tolerance, Citrate, Malate, Metabolizing enzymes

\section{Background}

Species of Eucalyptus are typical fast-growing hardwood trees. Their wide planting has had an important impact on the world timber market due to the high yield of lumber. Eucalyptus is naturally adapted to various environmental conditions, including acid soils $[1,2]$. Thus, Eucalyptus plantations have been established in acidic soils that are widely distributed in tropical and subtropical climate zones, including in south China. However, it is widely recognized that $\mathrm{Al}^{3+}$ is solubilized into the soil solution and is rhizotoxic to plants when soil $\mathrm{pH}$ is below 5.0 [3]. Thus, it is of great interest that acid soils caused no reduction in Eucalyptus productivity [2].

Various strategies have evolved in higher plants to alleviate $\mathrm{Al}$ phytotoxicity, ranging from external repulsion mechanisms to internal endurance mechanisms [4-6]. Aluminium-induced production of organic acids is considered to be one of the key tolerance mechanisms for detoxifying both internal and external $\mathrm{Al}[7,8]$. The accumulation of $\mathrm{Al}$ in root tips usually leads to rapid inhibition of root growth within minutes to hours by affecting the absorption of nutrients and disrupting other physiological processes [9]. Several studies have suggested that species of Eucalyptus have higher tolerance to $\mathrm{Al}$ toxicity than other tree species such as Quercus robur, Pinus radiata and Melaleuca cajuputi, and may even benefit from low concentrations of $\mathrm{Al}$ [10-12]. Moreover, species of Eucalyptus and their clones vary in their $\mathrm{Al}$ tolerance and response to $\mathrm{Al}$ in acidic environments [12-17]. As in other plants, the exudation of low molecular weight organic acids from the roots of several species or genotypes of Eucalyptus may be an important determinant for $\mathrm{Al}$ tolerance and may allow Eucalyptus to grow and yield well in acidic soils $[13,18,19]$. In recent years, asexual hybrid clones of fast-growing Eucalyptus have been the main source of high-yielding plantation stock. Knowledge of the role of organic acids in Al-tolerance of these superior hybrid clones grown in aluminized acidic soils is limited and needs further elucidation.

Citrate and malate are the main Al-chelating organic acids that confer tolerance to $\mathrm{Al}$ in plants. The types of organic acids and their transportation pathways that are induced by $\mathrm{Al}$ vary among different plant species and genotypes [20]. Aluminium-activated organic acid secretion is driven by passive outward movement down a concentration gradient that requires anion channels. In some crops, the activity of organic acid anion channels were more rapidly induced in Al-tolerant genotypes than in sensitive genotypes [21]. This rapid induction of organic acid secretion is mainly due to pre-existing membrane-localized anion channel proteins encoded by ALMT (Al-activated malate transporter) or MATE (Alactivated citrate transporter) genes [22, 23]. When there is a time delay in Al-induced organic acid secretion, new proteins involved in organic acid secretion can be synthesized within hours [2, 24]. Sawaki et al. [1] showed that in Eucalyptus camaldulensis citrate excretion through citrate-transporting EcMATE proteins was an important Al-tolerance mechanism. However, more work is needed on Al-induced secretion of organic acids from the root to determine whether there are other key components that may impact on the secretion process.

Low molecular weight organic acids involved in tricarboxylic acid (TCA) cycle, such as citrate and malate, are mainly synthesized in mitochondria. The synthesis and secretion of $\mathrm{Al}^{3+}$-induced organic acids are affected by changing activities of enzymes involved in Organic Anion (OA) metabolism and altering expression of corresponding genes [25], but these effects vary depending on plant species and genotype. In soybean, a cytosolic malic enzyme (ME) encoded by $G m M E 1$ contributed to increased internal malate and citrate concentrations and their efflux, conferring higher $\mathrm{Al}$ resistance [26]. In alfalfa, overexpression of genes encoding citrate synthase (CS) and malate dehydrogenase (MDH) led to increased concentrations and exudation of citrate and malate, and increased $\mathrm{Al}$ resistance [27]. Thus, increasing enzyme activities related to increasing malate and citrate production are effective in conferring $\mathrm{Al}$ tolerance to plants.

In previous research, we determined that Eucalyptus hybrid E. grandis $\times$ E. urophylla GL-9 (designated G9 here) was more Al-tolerant than E. urophylla GL-4 (designated W4 here) [28-30]. Lima et al. [16] reported that E. grandis possessed higher Al-tolerance than E. platyphylla due to a minor increase in reactive oxygen species 
and fewer alterations to stress indicators when exposed to high $\mathrm{Al}$. We concluded that $E$. grandis $\times E$. urophylla was more Al-tolerant than E. urophylla based on the low level induction of physiological antioxidant indicators [29]. Based on these results, we inferred that hybridization contributed to $\mathrm{Al}$-tolerance in E. grandis $\times$ E. urophylla, and provided it with the ability to acclimate to the acidic soils found throughout south China. Based on previous identification of organic acids secreted by Eucalyptus roots [2, 13, 18, 19], we hypothesized that citrate would be the main organic acid involved in $\mathrm{Al}$ detoxification in G9, and that malate may not have an important role. In addition to expecting higher CS activity in Al-tolerant G9 than W4, we also hypothesized that changes in other enzymatic activities associated with OA metabolism would support an increase in citrate accumulation. Such metabolic acclimations would provide further information to support strategies to increase $\mathrm{Al}$ tolerance in Eucalyptus and would be expected to be applicable to other species.

\section{Results}

\section{Accumulation of Al in roots of Eucalyptus}

Treatment with $\mathrm{Al}$ over a $24 \mathrm{~h}$ time course caused significantly higher Al concentrations in root tips of both G9 and W4 genotypes compared to the absence of $\mathrm{Al}$ (Fig. 1). The $\mathrm{Al}$ concentration peaked at $1 \mathrm{~h}$ in G9 root tips, and then declined by about $65 \%$ over the remainder of the time course. In W4 root tips, the $\mathrm{Al}$ concentration rose more rapidly than in G9 and continued to increase until around $6 \mathrm{~h}$, after which it declined somewhat. The $\mathrm{Al}$ concentration was higher in W4 root tips than in G9 root tips at all points of the time course. The lower accumulation of $\mathrm{Al}$ in $\mathrm{G} 9$ root tips indicated that the degree of $\mathrm{Al}$ exclusion differed between the two Eucalyptus clones that had differential tolerance to Al. This result was similar to that in our previous study on $\mathrm{Al}$ accumulation in 7-month-old soil-grown Eucalyptus seedlings exposed to $\mathrm{Al}$ for 4 months. The $\mathrm{Al}$ concentration in roots, stems and leaves of G9 was lower than those of W4 [31]. Taken together, these results suggested that G9 may have a greater ability to exclude $\mathrm{Al}$ from the interior of the root by chelating $\mathrm{Al}$ around its rhizosphere, thereby reducing $\mathrm{Al}$ absorption.

\section{Al-induced secretion of organic acids from roots of Eucalyptus}

The Al-inducible malate and citrate secretion from roots was compared between the contrasting clones over a 24 h time course (Fig. 2). The amount of malate secreted from roots was generally lower for each clone than the amount of citrate secreted in both the non-Al-treated controls (CK) and the Al-treated plants. Clone G9 had a higher level of organic acid secretion than W4 at all time points after the start of the $\mathrm{Al}$ exposure. The

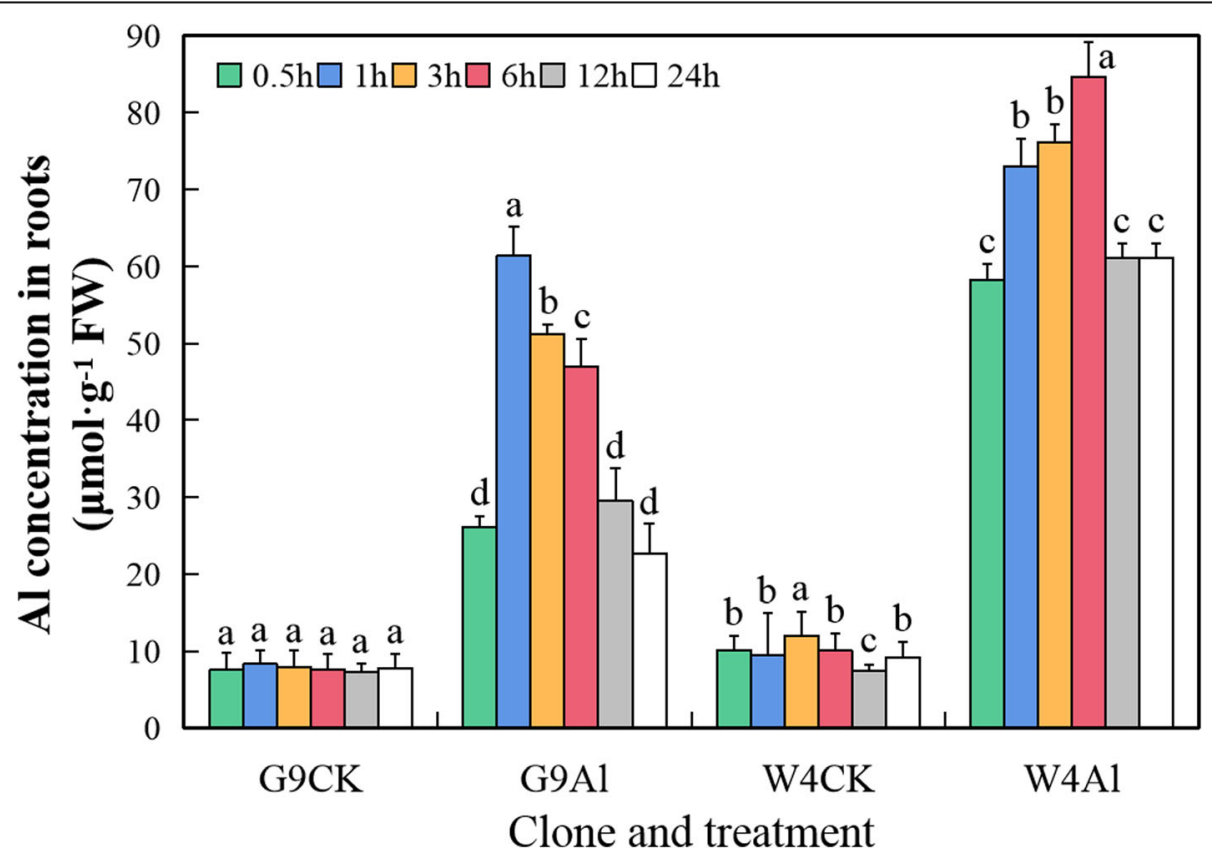

Fig. 1 Aluminum concentration in root tips of E. grandis $\times$ E. urophylla G9 and E. urophylla W4 at the indicated times after addition of Al. Bars represent means \pm standard errors $(n=3)$. Different letters above the bars indicate a significant difference at $P<0.05$. CK, non-Al-treated control; Al, aluminium treated 

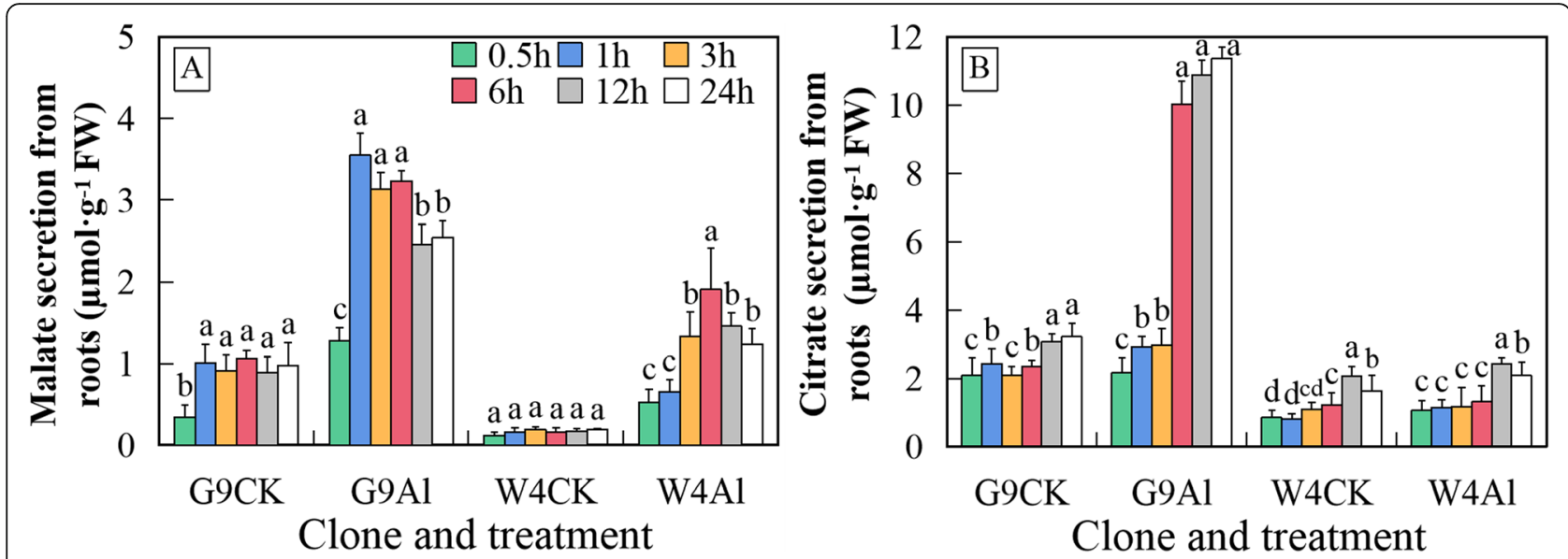

Fig. 2 Aluminium-induced malate (a) and citrate (b) excretion from roots of E. grandis $\times$ E. urophylla G9 and E. urophylla W4 into growth media at the indicated times after initiation of Al treatment. Growth media containing root exudates was sampled at each time point after the addition of $\mathrm{Al}$ at the same time that the seedlings were harvested. Data are means \pm standard error $(n=3)$. Different letters above the bars indicate a significant difference at $P<0.05$. CK, non-Al-treated control; Al, aluminium treated

accumulation of malate in G9 peaked around $1 \mathrm{~h}$ after exposure to $\mathrm{Al}$ and then decreased gradually, but was still more than 2-fold higher than the concentration in the absence of $\mathrm{Al}$ after $24 \mathrm{~h}$. (Fig. 2a). In clone W4, by contrast, the accumulation of malate reached its maximum after $6 \mathrm{~h}$ of $\mathrm{Al}$ treatment. The maximum in W4 was only about $60 \%$ of that in G9. Citrate accumulation for G9 was activated after $3 \mathrm{~h}$ of $\mathrm{Al}$ exposure and peaked by $6 \mathrm{~h}$, while there was no significant change in citrate accumulation in W4 through $24 \mathrm{~h}$ (Fig. 2b). These results indicated that the secretion mechanisms of these two organic acids differed between the tolerant and sensitive genotypes of Eucalyptus.

\section{Effect of inhibitors on organic acid secretion by Eucalyptus clones with contrasting Al tolerance}

To investigate the secretory pathways for citrate and malate from roots after $\mathrm{Al}$ treatment, the anion-channel inhibitor phenyglyoxal (PG) and the protein-synthesis inhibitor cycloheximide (CHM) were added at the start of a 24-h Al treatment (Fig. 3). Phenyglyoxal fully inhibited Al-induced malate secretion in both G9 and W4. In fact, PG also inhibited the non-Al-inducible secretion of malate in G9 to the same low background level observed in W4. The impact of CHM treatment on malate secretion in G9 was similar to that seen for PG treatment. However, CHM had no effect on the Al-induced secretion of malate in W4. The Al-induced secretion of citrate in both G9 and W4 was inhibited by CHM to the same low level, which was below the level of citrate secretion in the absence of $\mathrm{Al}$.

\section{Organic acid concentrations in root tips of Eucalyptus clones with contrasting Al tolerance}

No significant differences were found in the internal concentrations of malate or citrate in root tips in the absence of Al (Fig. 4). After 24-h exposure to Al, the citrate and malate concentrations in G9 increased by about 50 and 25\%, respectively, compared to the control. Thus, G9 root tips acclimated to Al stress by accumulating citrate and malate, which then allowed their secretion to the outside of the root. Meanwhile, the concentration of malate in W4 root tips upon exposure to $\mathrm{Al}$ decreased by about $70 \%$, but no change was observed for citrate. The presence of PG or CHM significantly inhibited the accumulation of both malate and citrate in the root tips of both clones to below the level observed in the absence of Al. The inhibition in Al-induced accumulation of the organic acids was over $90 \%$ in all cases except for the inhibition of malate accumulation in W4, which was $76 \%$ from a lower starting level.

\section{Activities of acid-metabolizing enzymes in root tips of Eucalyptus clones with contrasting Al tolerance}

The activities of phosphoenolpyruvate carboxylase (PEPC), MDH, ME, isocitrate dehydrogenase (IDH), aconitase (ACO) and CS were examined in root tips of plants exposed to $\mathrm{Al}$ and inhibitors (Fig. 5). PEPC, MDH and $\mathrm{ME}$ are important enzymes associated with the metabolism of malate. In the absence of $\mathrm{Al}$, the activity of PEPC was higher in root tips of G9 than of W4. There was a significant increase in PEPC activity in root tips of both clones after $\mathrm{Al}$ treatment, but the activity was below non-treated control levels when either PG or 

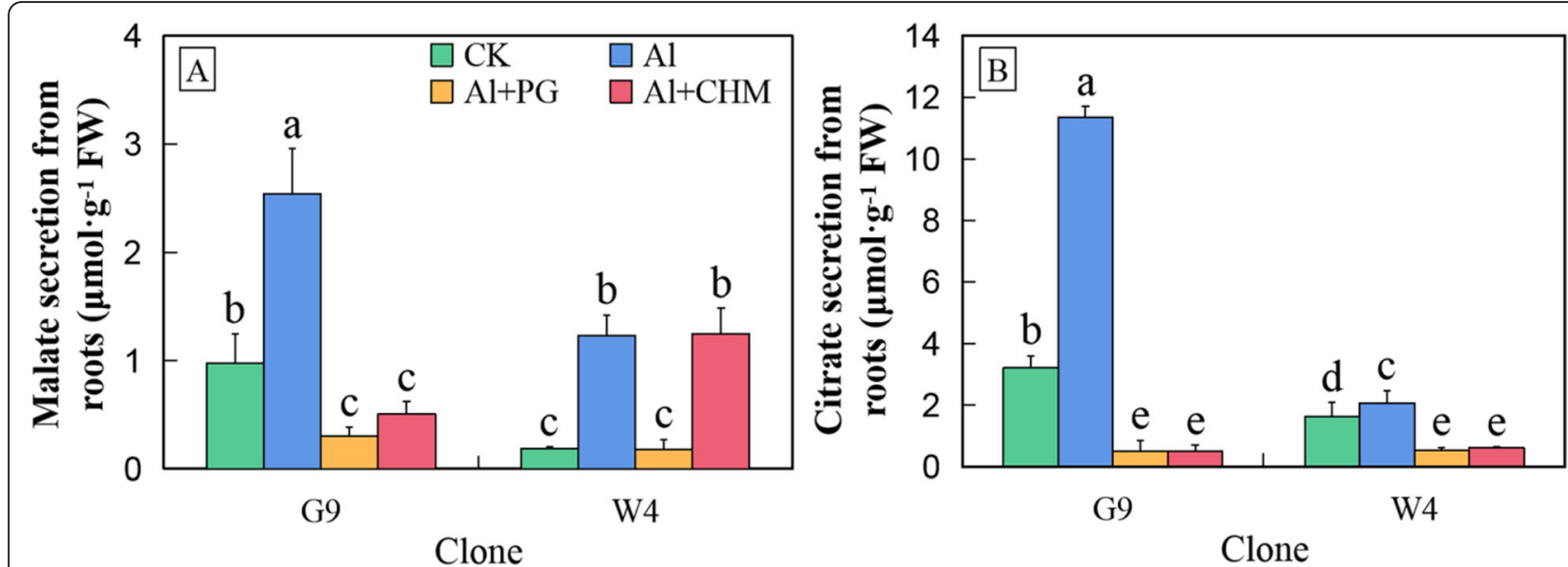

Fig. 3 Malate (a) and citrate (b) secreted from roots of E. grandis $\times$ E. urophylla G9 and E. urophylla W4 after $24 \mathrm{~h}$ of exposure to aluminium in the absence or presence of the anion channel inhibitor phenylglyoxyl $(P G)$ or the protein synthesis inhibitor cycloheximide (CHM). Bars represent means \pm standard errors $(n=3)$. Different letters above the bars indicate a significant difference at $P<0.05$. CK, non-Al-treated control

$\mathrm{CHM}$ were included in the $\mathrm{Al}$ treatment. In G9, the addition of inhibitors resulted in $80 \%$ lower PEPC activity compared to the addition of $\mathrm{Al}$ alone. $\mathrm{MDH}$ and $\mathrm{ME}$ activities were significantly lower in G9 after Al treatment than in the absence of $\mathrm{Al}$ treatment, as was the activity of ME in W4. In contrast, the activity of MDH in W4, which was already as low as in Al-treated G9, was unaffected by Al treatment. Interestingly, compared with the treatment with $\mathrm{Al}$ alone, the activity of $\mathrm{MDH}$ in G9 increased significantly after the addition of both PG and CHM, while the activity of MDH in W4 and ME in both clones remained unchanged by the addition of these inhibitors.
$\mathrm{IDH}, \mathrm{ACO}$ and $\mathrm{CS}$ are closely associated with citric acid metabolism. Compared to the non-Al treatment, $\mathrm{IDH}$ and $\mathrm{ACO}$ activities in W4 root tips exposed to $\mathrm{Al}$ were significantly higher, while CS activity was unchanged. In contrast, in root tips of Al-treated G9, IDH activity was unchanged, ACO activity was much lower and CS activity was 2-fold higher than in the absence of $\mathrm{Al}$ treatment. The increased activity of CS may be one of the main reasons for the higher Al-induced accumulation and secretion of citrate in G9. Both PG and CHM had no impact on the low activity of IDH in root tips of Al-treated G9, but repressed the $\mathrm{Al}$-induced increase in CS activity and relieved the Al-induced loss of ACO
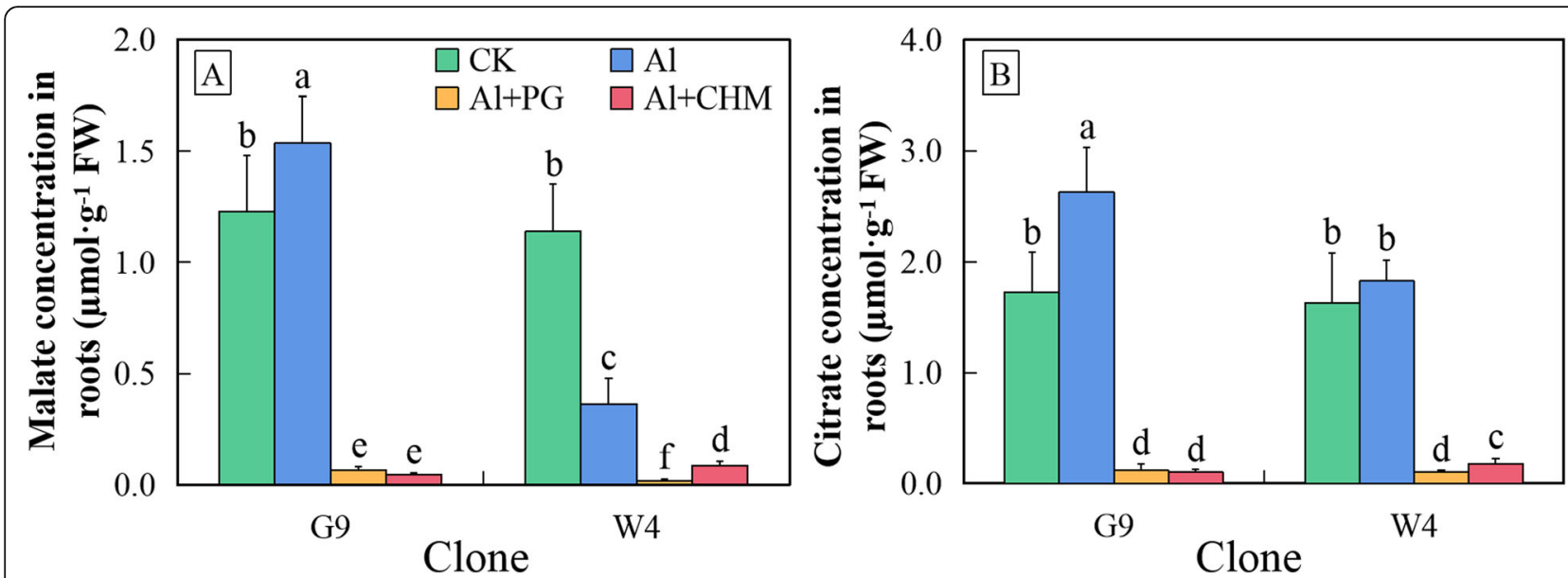

Fig. 4 Malate (a) and citrate (b) concentrations in root tips of E. grandis $\times$ E. urophylla G9 and E. urophylla W4 after $24 \mathrm{~h}$ treatment with aluminium in the absence or presence of the anion channel inhibitor phenylglyoxyl (PG) or the protein synthesis inhibitor cycloheximide (CHM). Bars represent means \pm standard errors $(n=3)$. Different letters above the bars indicate significant differences at $P<0.05$. CK, non-Al-treated control 

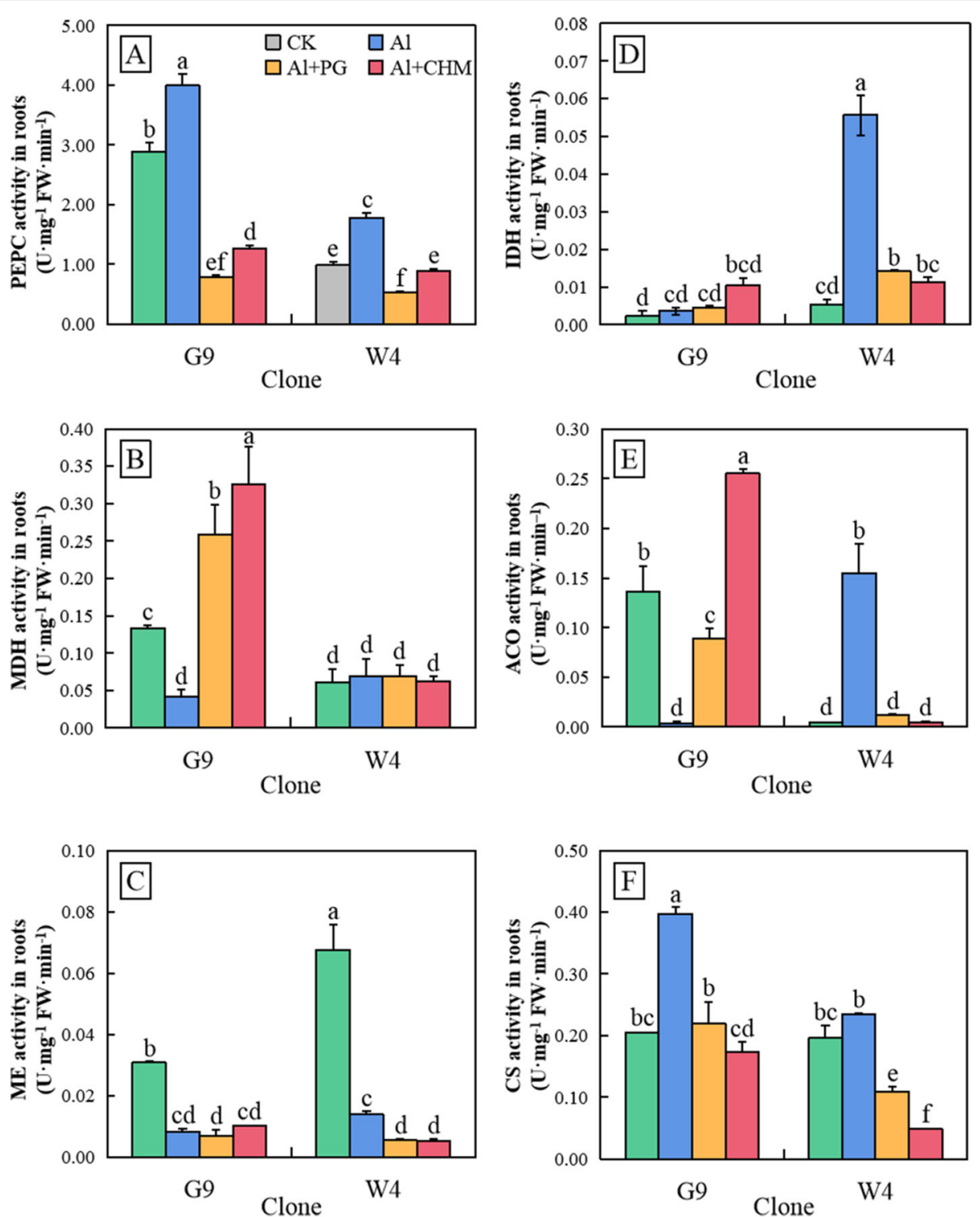

Fig. 5 Activities of PEPC (a), MDH (b), ME (c), IDH (d), ACO (e) and CS (f) in root tips of E. grandis $\times$ E. urophylla G9 and E. urophylla W4 after $24 \mathrm{~h}$ treatment with aluminium in the absence or presence of the anion-channel inhibitor phenylglyoxyl (PG) or the protein-synthesis inhibitor cycloheximide $(\mathrm{CHM})$. Bars represent means \pm standard errors $(n=3)$. Different letters above the bars indicate significant differences at $P<0.05$. CK, non-Al-treated control

activity. In Al-treated W4 root tips, the two inhibitors abolished the Al-induced increase in IDH and ACO, and lowered the CS activity to below that in the untreated control.

\section{Discussion}

\section{An Al-tolerant Eucalyptus hybrid clone has enhanced accumulation and exudation of malate and citrate}

The available evidence indicates that the Al-induced secretion of organic acids from roots may lead to the detoxification of $\mathrm{Al}$ in higher plants [32, 33]. A role for organic acids leading to $\mathrm{Al}$ tolerance in Eucalyptus has been observed previously $[12,18,19]$. The lower root tip concentration of $\mathrm{Al}$ coupled with the higher root secretion of citrate and malate in Al-tolerant $E$. grandis $\times E$. urophylla clone G9 than that in Al-sensitive E. urophylla clone W4 suggested that secretion of these two organic acids was involved in the increased tolerance to $\mathrm{Al}$ in G9. This trait was consistent with the results reported for Al-tolerant E. camaldulensis [12, 18, 34]. Tahara et al. [12] documented in E. camaldulensis that citrate had the strongest capacity to bind $\mathrm{Al}$ among citrate, oxalate, malate and phosphate. Thus, it was likely that the Al-stimulated accumulation and secretion of citrate was 
the main underlying mechanism contributing to detoxification of $\mathrm{Al}$ by Eucalyptus roots, particularly in Altolerant genotypes. However, Silva et al. [19] put forward the hypothesis that $\mathrm{Al}$ tolerance was due to the internal detoxification of $\mathrm{Al}$ by complexation with malate. These conflicting conclusions left the role of malate in Eucalyptus tolerance unclear. Adding to the complexity, the types of organic acids produced and released in response to Al may vary among Eucalyptus species [34], as do the quantities, as shown here for malate and citrate. The features of malate and citrate accumulation and secretion in Al-tolerant hybrid clone G9 and Al-sensitive parental clone W4 have provided further clues for the identification $\mathrm{Al}$-induced genes or proteins.

\section{Newly synthesized carrier proteins involved in citrate secretion, but malate secretion facilitated by a pre- existing anion channel in $E$. grandis $\times E$. urophylla}

A rapid release of organic acid in response to exposure to $\mathrm{Al}$ would suggest that pre-existing anion transporters on the plasma membrane quickly initiated organic acid secretion without the need to produce new proteins; however, a lag in the release of organic acids could indicate that gene expression and/or protein synthesis was required $[33,35,36]$. There was no significant delay in malate secretion by G9, followed by an increase in the secretion of citrate after a lag period of more than $3 \mathrm{~h}$. In contrast, in W4, there was a lag of more than an hour after $\mathrm{Al}$ exposure before malate secretion became apparent, while $\mathrm{Al}$ exposure did not induce the production or secretion of citrate. Thus, $24 \mathrm{~h}$ after exposure to $\mathrm{Al}$, the synthesis and secretion of malate and citrate by G9 was much greater than in W4.

Both PG and CHM significantly reduced the $\mathrm{Al}-$ induced secretion and internal concentration of citrate in roots of both Eucalyptus clones as well as the malate concentration in G9. However, CHM had no impact on malate secretion in W4, indicating that there are different pathways operating for citrate and malate secretion in response to $\mathrm{Al}$ in the two clones. Generally, Altolerant species or genotypes had stronger induction and higher quantities of carrier proteins on membranes inside root cells and anion channel proteins on the plasma membrane of root cells, than $\mathrm{Al}$-sensitive genotypes [37, 38]. If organic acid synthesis and transport require the involvement of newly synthesized carrier proteins, an obvious lag of several hours before secretion would be apparent, while pre-existing anion channel proteins would allow organic acids to be secreted out of the root more quickly [39, 40]. Therefore, in G9, it seems likely that pre-existing anion channel proteins facilitated the immediate secretion of malate, while a new carrier protein apparently had to be produced before citrate could be transported out of the roots. Anion channel proteins, such as ALMT and MATE/AACT, are localized to the plasma membrane of root cells and transport their substrates to rapidly facilitate organic acid release at phytotoxic concentrations of $\mathrm{Al}^{3+}[41,42]$. Furthermore, numerous genes encoding OA transporters have been found to increase OA secretion and to be involved in $\mathrm{Al}$ detoxification [43, 44]. Sawaki et al. [1] reported that Al-induced excretion of citrate by $E$. camaldulensis roots was associated with higher expression of EcMATE on the plasma membrane, and that the ectopic expression of EcMATE in tobacco hairy roots enhanced Alresponsive citrate excretion, providing further insight into the molecular mechanism underlying $\mathrm{Al}$ resistance in Eucalyptus and the potential for genetic improvement of Eucalyptus. However, other components remain to be revealed, particularly the new proteincoding genes and their functions in organic acid synthesis and transport. For instance, the delay in citrate secretion found in G9 was likely due to the need to produce new proteins involved in the synthesis and delivery of citric acid. For W4, there was no change in citrate secretion in response to exposure to $\mathrm{Al}$, while malate secretion was delayed and did not reach its maximum level for $6 \mathrm{~h}$. Moreover, $\mathrm{CHM}$ had no effect on the secretion of malate, but did inhibit its accumulation, indicating that W4 does not lack the capacity to release malate, but rather was restricted in its ability to produce malate.

Increasing organic acids exudation may not be the only effective way to enhance $\mathrm{Al}$ resistance of Eucalyptus. We speculate that other organic substances might be involved in detoxifying $\mathrm{Al}$ in some Eucalyptus genotypes. A consequence of $\mathrm{Al}$ tolerance in Eucalyptus was the maintenance of nutrients and photosynthesis [17, 45]. A new low-molecular-weight Al-binding ligand from roots, oenothein $\mathrm{b}$, contributed to $\mathrm{Al}$ tolerance in $E$. camaldulensis $[12,46]$. In addition, a number of allelochemicals were detected in E. grandis roots and soil by GC-MS [47, 48]. Many of these chemicals are involved in either primary or secondary plant metabolism and plant defense processes [49]. These process may interfere with the secretion of low molecular organic acids, or their products may form complexes with Al. For example, one study found that phenolic compounds could be involved in $\mathrm{Al}$ detoxification forming strong complexes with $\mathrm{Al}$ ions in the cytoplasm of woody plants including E. viminalis Labill [50]. In addition, transcriptome analysis has revealed that genes associated with flavonoid and phenylpropanoid biosynthetic pathways have key roles in the response of roots of Cunninghamia lanceolata (lamb.) hook. to Al [51]. All these findings encourage further research to identify compounds and the related genes that confer $\mathrm{Al}$ tolerance to 
hybrid clones of Eucalyptus, including the contributions made by allelopathic compounds and other root exudates.

\section{Secretion and accumulation of citrate and malate in hybrid clone $E$. grandis $\times$ E. urophylla GL-9 were closely linked with changes in CS and PEPC activities}

We observed that CS and PEPC activities in root tips of both clones were markedly induced by $\mathrm{Al}$, while $\mathrm{ME}$ activity was significantly decreased. Together, these changes likely contribute to the increased biosynthesis of organic acids by feeding carbon skeletons into the TCA cycle [52]. The balance between synthesis or catabolism of Al-induced citrate and malate was regulated by shifts in activities of various metabolic enzymes that together contributed to accumulation of these organic acids to increase $\mathrm{Al}$ tolerance in Eucalyptus. Additionally, the addition of inhibitors (PG and $\mathrm{CHM}$ ) directly or indirectly caused changes in enzyme activities involved in organic acid metabolism.

In the case of E. urophylla clone W4, decreased ME activity may play a greater role in the lower accumulation of malate upon exposure to $\mathrm{Al}$, since $\mathrm{MDH}$ activity was unchanged. Meanwhile, the activities of ACO and $\mathrm{IDH}$ were significantly increased by $\mathrm{Al}$ exposure, which may underlie the lack of an increase in citrate. In $E$. grandis $\times E$. urophylla clone G9, increased synthesis and secretion of malate seemed to be supported by decreased ME and MDH activity to prevent malate metabolism. We speculate that genes encoding ME may contribute to increased internal malate and citrate concentrations, leading to exudation of these organic acids to confer higher Al resistance, as in soybean [26]. CS is typically regarded as the main enzyme necessary to increase synthesis and secretion of citrate in roots of $\mathrm{Al}$-tolerant plants, such as rye [53], Paraserianthes facataria [54], and soybean [55]. Moreover, transcript levels specifying CS, ALMT and MATE in the root apex of an Altolerant cultivar of alfalfa were higher than in an Alsensitive cultivar [27]. However, Ikka et al. [34] found that the $\mathrm{Al}$-induced increase in citrate concentration in roots of E. camaldulensis was not due to increased CS activity, but was dependent on reduced ACO activity, which would suppress citrate catabolism. Recently, Teng et al. [56] reported that CS, PEPC and IDH may play important roles in organic acid biosynthesis and degradation in Eucalyptus. Our study indicated that the increased synthesis and secretion of citrate that contributed to increase Al-tolerance in E. grandis $\times$ E. urophylla was likely achieved by increasing the activities of PEPC and CS, and decreasing the activity of ACO. These three enzymes may be involved in creating the balance between the secretion of malate and citrate in the roots of plants exposed to $\mathrm{Al}$.
From the above, it is clear that key enzymes regulating OA synthesis and exudation vary among of Eucalyptus genotypes. Alterations in the expression of the corresponding genes can affect $\mathrm{OA}$ synthesis and exudation resulting in changes in Al tolerance [57]. Some effort has been made in plants to increase the expression of enzymes such as PEPC, CS and MDH by introducing genes encoding these enzymes, for example, in tobacco, alfalfa and canola. Overexpression of these genes would be expected to increase organic acid metabolism and may produce a new citrate synthesis pathway that would contribute to increased $\mathrm{Al}$ tolerance in transgenic plants [58-60]. For example, in transgenic canola, overexpression of a CS gene not only led to increased citrate synthesis and exudation, but also changed malate metabolism, which may improve tolerance to $\mathrm{Al}$ toxicity [57, 61, 62]. Since previous studies have indicated that the synthesis of organic acids could be increased by regulating the expression of genes encoding enzymes involved in OA synthesis or transporters involved in OA secretion, transgenic approaches can be expected to provide higher $\mathrm{Al}$ tolerance in plants, including Eucalyptus.

\section{Conclusion}

It appears that both citrate and malate contributed to $\mathrm{Al}$ tolerance in Eucalyptus and that both accumulation and secretion of these organic acids were involved in Al detoxification. The superior performance of hybrid clone $E$. grandis $\times E$. urophylla for high yield on aluminized acidic soils was closely associated with increased capacity to release both citrate and malate. Citrate had a more important role in the response to $\mathrm{Al}$ in E. grandis $\times$ E. urophylla than in E. urophylla. In addition, PG and CHM treatments indicated that both anion channel proteins and increased carrier protein synthesis were involved in $\mathrm{Al}$-induced secretion of citrate in Al-tolerant E. grandis $\times E$. urophylla, but the secretory pathway for malate remained unclear. The enhanced activities of CS and PEPC and the reduced activities of IDH, ACO and ME contributed to Al-induced accumulation and secretion of citrate and malate, demonstrating that metabolic adaptations are associated with $\mathrm{Al}$-tolerance in E. grandis $\times E$. urophylla. More effort is needed to identify and isolate the genes associated with organic acid transport in Eucalyptus, or introduce exogenous genes to make specific enzymes overexpressed and have high activity, further advance Al-tolerance in superior hybrids of Eucalyptus. Meanwhile, other compounds which could be involved in $\mathrm{Al}$ detoxification also need further investigation and elucidation of their regulatory mechanism.

\section{Methods}

Plant material

Two clones of Eucalyptus, Al-tolerant E. grandis $\times E$. urophylla GL-9 (Voucher number: 桂S-SC-EGU-023- 
2011; designated G9) and Al-sensitive E. urophylla GL-4 (Voucher number: 桂S-SC-EU-022-2011; designated W4) were used in this study. Two-month-old seedlings from culture were provided by the Guangxi Forestry Research Institute, Nanning, China. Guo Dongqiang, a senior engineer and researcher formally identified the two clones [see Additional files 1, 2 and 3]. Seedlings of similar appearance and size were placed in $2 \mathrm{~L}$ plastic buckets containing nutrient solution with 10 seedlings per bucket. All solutions were prepared with deionized water. For acclimating plants to the hydroponic culture system before $\mathrm{Al}$ treatment, seedlings were pre-cultured in $20 \%$ nutrient solution, pH 5.0 for 3 days, then in $50 \%$ nutrient solution, $\mathrm{pH} 4.5$ for a further 3 days. Acclimated seedlings were transferred to $100 \%$ nutrient solution, $\mathrm{pH} 4.0$ for 7 days. The composition of $100 \%$ nutrient solution was $6 \mathrm{mM} \mathrm{KNO} 3,5 \mathrm{mM} \mathrm{Ca}\left(\mathrm{NO}_{3}\right)_{2}, 1 \mathrm{mM}$ $\mathrm{MgSO}_{4}, 2 \mathrm{mM} \mathrm{NH} \mathrm{H}_{2} \mathrm{PO}_{4}, 20 \mu \mathrm{M}$ Fe-EDTA, $31.25 \mu \mathrm{M}$ $\mathrm{H}_{3} \mathrm{BO}_{3}, 2 \mu \mathrm{M} \mathrm{MnCl} 2,2 \mu \mathrm{M} \mathrm{ZnSO}, 0.5 \mu \mathrm{M} \mathrm{CuSO}_{4}$ and $0.065 \mu \mathrm{M}\left(\mathrm{NH}_{4}\right)_{6} \mathrm{Mo}_{7} \mathrm{O}_{24}$. The $\mathrm{pH}$ was adjusted with 2 $\mathrm{mM} \mathrm{HCl}$. All nutrient solutions were renewed every 2 days. Prior to solution replacement, seedlings were sterilized with $0.1 \%(\mathrm{v} / \mathrm{v})$ carbendazim for $20 \mathrm{~min}$ to inhibit microorganisms. Air pumps were used to continuously aerate the seedlings in hydroponics at $50 \mathrm{~L}$ air $\mathrm{h}^{-1}$.

\section{Aluminum and inhibitor treatments}

After 7 days of culture in complete nutrient solution, $\mathrm{pH} 4.0$, seedlings were transferred to $2 \mathrm{~L}$ fresh nutrient solution, $\mathrm{pH} 4.0$, supplemented with or lacking $4.44 \mathrm{mM}$ $\mathrm{Al}^{3+}$ from $\mathrm{AlCl}_{3} \cdot 6 \mathrm{H}_{2} \mathrm{O}$ with ten seedlings per pot. Each treatment was carried out in triplicate $(3 \times 10$ plants $)$. The growth solution and roots were harvested from three pots at $0.5 \mathrm{~h}, 1 \mathrm{~h}, 3 \mathrm{~h}, 6 \mathrm{~h}, 12 \mathrm{~h}$, and $24 \mathrm{~h}$ from the start of exposure to $\mathrm{Al}^{3+}$. The internal concentration of citrate and malate and their concentration in the growth medium were determined at these time points. The activities of organic acid-metabolizing enzymes inside root tips were determined after $24 \mathrm{~h}$ of $\mathrm{Al}$ treatment.

To identify potential factors involved in organic acid secretion, the impact of the protein synthesis inhibitor $\mathrm{CHM}$, and the anion channel blocker PG were determined by cultivating the seedlings as above in solutions supplemented with $0.5 \mathrm{mg} \mathrm{L}^{-1} \mathrm{CHM}$ and $0.5 \mathrm{mg} \mathrm{L}^{-1}$ PG with 0 or $4.44 \mathrm{mM} \mathrm{Al}^{3+}$ for $24 \mathrm{~h}$. The secretion of citrate and malate from the roots was determined after $24 \mathrm{~h}$.

\section{Determination of organic acids in root exudates}

Samples were prepared following the methods of Wang et al. [63], with some modifications. The collected hydroponics solution was filtered through a mixed fiber membrane to obtain $50 \mathrm{~mL}$ filtrate. The filtrate was passed through a cation exchange column $(15 \mathrm{~mm} \times 11$ $\mathrm{cm}, 5 \mathrm{~g}$ Amerlite IR-120 resin), followed by an anion exchange column (2 g Dowex 1-X8 resin). The organic acids bound to the anion exchange column were eluted with $2 \mathrm{M} \mathrm{HCl}$. The eluent was condensed to dryness at $40^{\circ} \mathrm{C}$ by rotary evaporation (R215, Buchi, Switzerland). The dried eluent was re-dissolved into $1 \mathrm{~mL}$ of Milli-Q water, and filtered $(0.45 \mu \mathrm{m}$ membrane filter). The filtered solution was analyzed for citrate and malate using ion chromatography (ICS-5000 Ion Chromatography system with $4 \times 250 \mathrm{~mm}$ AS11-HC analytical column and $4 \times 50 \mathrm{~mm}$ AS11-HC guard column, Dionex, USA).

\section{Analysis of malate and citrate in root tips}

Harvested roots were rinsed with Milli-Q water to remove the hydroponics solution. The distal $2 \mathrm{~cm}$ containing the root apices were excised to extract and assay the internal concentration of citrate and malate following the methods of Dong et al. [64] and Tahara et al. [12] with some modifications. A total weight of $0.2 \mathrm{~g}$ for each sample was ground under liquid nitrogen before adding $1.5 \mathrm{~mL}$ ice-cold $4 \%(\mathrm{v} / \mathrm{v}) \mathrm{HClO}_{4}$ into the powder and gently homogenizing. The mixture was thawed slowly on ice into a suspension and allowed to stand for $30 \mathrm{~min}$, followed by centrifugation at $20,000 \times \mathrm{g}$ at $4{ }^{\circ} \mathrm{C}$ for 10 min. The supernatant was passed through an ion exchange column $(15 \mathrm{~mm} \times 11 \mathrm{~cm})$ filled with cation exchange resin (Amerlite IR-120 resin, $\mathrm{H}^{+}$form, USA) to remove cations, and was then passed through the a pretreatment column (RP18 column, Dionex, USA) to absorb plant pigments. The extracted malate and citrate in roots were determined by ICS as described above.

\section{Determination of $\mathrm{Al}$ in root tips}

Roots were rinsed with Milli-Q water three times. The 3 $\mathrm{cm}$ at root apices were excised and dried at $80^{\circ} \mathrm{C}$ before grinding to a fine powder. Powdered root tips $(100 \mathrm{mg})$ were digested in $10 \mathrm{~mL} \mathrm{HNO}_{3}: \mathrm{HClO}_{4}(5: 1 \mathrm{v} / \mathrm{v})$ until the solution was clear. The digest was diluted to $25 \mathrm{~mL}$ with Milli-Q water and the Al concentration in the solution was immediately determined by inductively coupled plasma atomic emission spectroscopy (5100 ICP- OES, Agilent Technologies, USA).

\section{Activity measurement of organic acid-metabolizing enzymes}

After plants were cultured for $24 \mathrm{~h}$ in the presence or absence of $\mathrm{Al}$, the activities of PEPC, MDH, CS, NADPdependent IDH, NADP-dependent NADP-ME and ACO were measured. Based on the methods of Chen et al. [65] and Yu et al. [38], $200 \mathrm{mg}$ of fresh root apices were homogenized in ice-cold extraction buffer containing 50 $\mathrm{mM}$ HEPES-NaOH, pH 7.5, $5 \mathrm{mM} \mathrm{MgCl}_{2}, 5 \mathrm{mM}$ EDTA, $10 \%(\mathrm{v} / \mathrm{v})$ glycerol, $0.1 \%(\mathrm{v} / \mathrm{v})$ Triton X-100, $1 \%(\mathrm{w} / \mathrm{v})$ PVPP (cross-linked polyvinylpyrrolidone) and $5 \mathrm{mM}$ dithiothreitol. After clarification by centrifugation at 15 , 
$000 \times g$ for $15 \mathrm{~min}$ at $4{ }^{\circ} \mathrm{C}$, the supernatant was used for enzyme activity determination. The activities were measured in a $3 \mathrm{~mL}$ reaction mixture using spectrophotometric assays described by Jenner et al. [66], Chen et al. [65] and Ikka et al. [34]. The activities of all enzymes were determined at $340 \mathrm{~nm}$, except CS activity was determined at $412 \mathrm{~nm}$.

\section{Data analysis}

Each treatment was done with three biological replicates of 10 plants each. Statistical analysis was performed using SPSS software package. All data between different treatments was compared using one-way analysis of variance with LSD test and significant differences between the means of two treatments were determined using the Duncan test at $P \leq 0.05$.

\section{Supplementary Information}

The online version contains supplementary material available at https://doi. org/10.1186/s12870-020-02788-4

Additional file 1. Certification of superior varieties of forest tree (Eucalyptus grandis $\times$ Eucalyptus urophylla).

Additional file 2. Certification of superior varieties of forest tree (Eucalyptus urophylla).

Additional file 3. Certification of Eucalyptus from Guangxi forestry research institute.

\section{Abbreviations}

CHM: Cycloheximide; PG: Phenylglyoxal; CS: Citrate synthase: PEPC: Phosphoenolpyruvate carboxylase; IDH: NADP-dependent isocitrate dehydrogenase; ACO: Aconitase; ME: NADP-dependent malic enzyme; ALMT: Al-activated malate transporter; MATE: Al-activated citrate transporter; TCA: Tricarboxylic acid; OA: Organic anion; MDH: Malate dehydrogenase; CK: Control check; AACT: Aluminum-activated citrate transporter; EDTA: Ethylene diamine tetraacetic acid; NADP: Nicotinamide adenine dinucleotide phosphate; PVPP: Crosslinked polyvinylpyrrolidone; DTT: Dithiothreitol

\section{Acknowledgements}

We thank Guangxi Forestry Research Institute for providing the clonal Eucalyptus seedlings used in this study.

\section{Authors' contributions}

WNL, QD and MY conceived and designed the research. WNL and QD collected, analyzed the data, and prepared the manuscript. GDQ cultured the Eucalyptus seedling and assisted in the determinations. MY and PMF discussed the results and revised the manuscript. All of the authors read and approved the manuscript.

\section{Funding}

This research was supported by grants from Guangxi Specific Grant for Innovation-driven Development Projects (AA17204087-6) and National Natural Science Foundation of China (31070560 and 31260176). We thank the Foundation of Economic Support. The funding organizations provided the financial support to the research projects, but were not involved in the design of the study, data collection, analysis of the data, or the writing of the manuscript.

\section{Availability of data and materials}

The datasets used and analysed during the current study available from the corresponding author on reasonable request.
Ethics approval and consent to participate

Not applicable.

\section{Consent for publication}

Not applicable.

\section{Competing interests}

The authors declare that the research was conducted in the absence of any commercial or financial relationships that could be construed as a potential conflict of interest.

\section{Author details}

${ }^{1}$ Guangxi Key Laboratory of Forest Ecology and Conservation, College of Forestry, Guangxi University, 100 East University Road, Nanning 530004, Guangxi, People's Republic of China. ${ }^{2}$ School of Biological Sciences, University of Western Australia, Perth 6009, Australia. ${ }^{3}$ Guangxi Forestry Rearch Institute, Nanning 530002, Guangxi, People's Republic of China.

Received: 14 May 2020 Accepted: 8 December 2020

Published online: 06 January 2021

\section{References}

1. Sawaki Y, Kihara-Doi T, Kobayashi Y, Nishikubo N, Kawazu T, Kobayashi Y, et al. Characterization of Al-responsive citrate excretion and citratetransporting MATEs in Eucalyptus camaldulensis. Planta. 2013;237:979-89.

2. Ye SM, Wen YG, Yang M, Liang HW. Correlation analysis on biodiversity and soil physical\& chemical properties of Eucalyptus spp. plantations under successive rotation. J Soil Water Conserv. 2010;24:246-51.

3. Kinraide TB. Identity of the rhizotoxic aluminium species. Plant Soil. 1991; 134:167-78

4. Kochian LV, Hoekenga OA, Piñeros MA. How do crop plants tolerate acid soils? Mechanisms of aluminum tolerance and phosphorous efficiency. Annu Rev Plant Biol. 2004:55:459-93.

5. Brunner I, Sperisen C. Aluminum exclusion and aluminum tolerance in woody plants. Front Plant Sci. 2013:4:1-12.

6. Xu QS, Wang Y, Ding ZT, Song LB, Li YS, Ma DX, et al. Aluminum induced metabolic responses in two tea cultivars. Plant Physiol Biochem. 2016;101: 162-72.

7. Barceló J, Poschenrieder C. Fast root growth responses, root exudates, and internal detoxification as clues to the mechanisms of aluminium toxicity and resistance: a review. Environ Exp Bot. 2002;48:75-92.

8. Kikui S, Sasaki T, Osawa H, Matsumoto H, Yamamoto Y. Malate enhances recovery from aluminum-caused inhibition of root elongation in wheat. Plant Soil. 2007:290:1-15.

9. Poschenrieder C, Gunsé B, Corrales I, Barceló J. A glance into aluminum toxicity and resistance in plants. Sci Total Environ. 2008:400:356-68.

10. Huang $\mathrm{JH}$, Bachelard EP. Effects of aluminium on growth and cation uptake in seedlings of Eucalyptus mannifera and Pinus radiata. Plant Soil. 1993;149: $121-7$.

11. Álvarez E, Fernández-Marcos ML, Monterroso C, Fernández-Sanjurjo MJ. Application of aluminium toxicity indices to soils under various forest species. For Ecol Manag. 2005;211:227-39.

12. Tahara K, Norisada M, Yamanoshita T, Kojima K. Role of aluminum-binding ligands in aluminum resistance of Eucalyptus camaldulensis and Melaleuca cajuputi. Plant Soil. 2008:302:175-87.

13. Tahara K, Norisada M, Hogetsu T, Kojima K. Aluminum tolerance and aluminum-induced deposition of callose and lignin in the root tips of Melaleuca and Eucalyptus species. J For Res. 2005;10:325-33.

14. Tahara K, Hashida K, Otsuka Y, Ohara S, Kojima K, Shinohara K. Identification of a hydrolyzable tannin, oenothein $B$, as an aluminum-detoxifying ligand in a highly aluminum-resistant tree, Eucalyptus camaldulensis. Plant Physiol. 2014;164:683-93.

15. De Alcântara BK, Pizzaia D, Piotto FA, Borgo L, Brondani GE, Azevedo RA Temporal dynamics of the response to al stress in Eucalyptus Grandis X Eucalyptus Camaldulensis. An Acad Bras Cienc. 2015;87:1063-70.

16. Lima MDR, Barbosa MAM, Batista BL, Lobato AK da S. Biochemical responses of two species of Eucalyptus exposed to aluminium toxicity: oxidative stress and antioxidant metabolism. Not Bot Horti Agrobot Cluj-Napoca. 2016:44: $107-15$ 
17. Silva LFF, Lima MDR, Lima EJA, Castro ARS, Barros Junior UO, Lobato AKS. Differential behaviours in two species of Eucalyptus exposed to aluminium. Indian J Plant Physiol. 2017;22:107-13.

18. Nguyen NT, Nakabayashi K, Thompson J, Fujita K. Role of exudation of organic acids and phosphate in aluminum tolerance of four tropical woody species. Tree Physiol. 2003;23:1041-50.

19. Silva IR, Novais RF, Jham GN, Barros NF, Gebrim FO, Nunes FN, et al. Responses of eucalypt species to aluminum: the possible involvement of low molecular weight organic acids in the Al tolerance mechanism. Tree Physiol. 2004;24:1267-77.

20. Eldhuset TD, Swensen B, Wickstrøm T, Wollebæk G. Organic acids in root exudates from Picea abies seedlings influenced by mycorrhiza and aluminum. J Plant Nutr Soil Sci. 2007;170:645-8.

21. Kopittke PM, McKenna BA, Karunakaran C, Dynes JJ, Arthur Z, Gianoncelli A, et al. Aluminum complexation with malate within the root apoplast differs between aluminum resistant and sensitive wheat lines. Front Plant Sci. 2017; 8:1-11.

22. Sasaki T, Yamamoto Y, Ezaki B, Katsuhara M, Ahn SJ, Ryan PR, et al. A wheat gene encoding an aluminum-activated malate transporter. Plant J. 2004;37: 645-53.

23. Furukawa J, Yamaji N, Wang H, Mitani N, Murata $Y$, Sato $K$, et al. An aluminum-activated citrate transporter in barley. Plant Cell Physiol. 2007;48: 1081-91.

24. Yang JL, Zheng SJ, He YF, You JF, Zhang L, Yu XH. Comparative studies on the effect of a protein-synthesis inhibitor on aluminium-induced secretion of organic acids from Fagopyrum esculentum Moench and Cassia tora L. roots. Plant. Cell Environ. 2006;29:240-6.

25. Ryan PR, Delhaize E, Jones DL. Function and mechanism of organic anion exudation from plant roots. Annu Rev Plant Physiol Plant Mol Biol. 2001;52:27-60.

26. Zhou Y, Yang ZM, Xu YZ, Sun HR, Sun ZT, Lin B, et al. Soybean NADP-malic enzyme functions in malate and citrate metabolism and contributes to their efflux under Al stress. Front Plant Sci. 2018;8:1-11.

27. Sun GL, Zhu HF, Wen SL, Liu LS, Gou LM, Guo ZF. Citrate synthesis and exudation confer Al resistance in alfalfa (Medicago sativa L.). Plant Soil. 2020;449:319-29.

28. Yang $M$, Huang SX, Fang SZ, Huang XL. Response of seedling growth of four Eucalyptus clones to acid and aluminum. Plant Nutr Fertil Sci. 2011;17:195-201.

29. Yang M, Wu YM, Huang SX, Huang XL. Resistance physiological response of different fast- growing Eucalyptus clones to acid- aluminum stresses. Sci Silva Sin. 2011;47:181-7.

30. Yang M, Tan L, Xu YY, Zhao YH, Cheng F, Ye SM, et al. Effect of low pH and aluminum toxicity on the photosynthetic characteristics of different fastgrowing Eucalyptus vegetatively propagated clones. PLoS One. 2015;10:1-15.

31. Yang $M$, Cao XN, Wu YM, Huang XL. Effect of acid aluminum on absorption of Al and N,P,K in Eucalyptus Clones with different aluminum tolerance. Southwest China J Agric Sci. 2012;25:1061-4.

32. Ma JF. Physiological mechanisms of Al resistance in higher plants. Soil Sci Plant Nutr. 2005;51:609-12.

33. Ma JF. Role of organic acids in detoxification of aluminum in higher plants Plant Cell Physiol. 2000;41:383-90.

34. Ikka T, Ogawa T, Li D, Hiradate S, Morita A. Effect of aluminum on metabolism of organic acids and chemical forms of aluminum in root tips of Eucalyptus camaldulensis Dehnh. Phytochemistry. 2013;94:142-7.

35. Kollmeier M, Dietrich $\mathrm{P}$, Bauer CS, Horst WJ, Hedrich R. Aluminum activates a citrate-permeable anion channel in the aluminum-sensitive zone of the maize root apex. A comparison between an aluminum- sensitive and an aluminum-resistant cultivar. Plant Physiol. 2001;126:397-410.

36. Ryan PR, Dong B, Watt M, Kataoka T, Delhaize E. Strategies to isolate transporters that facilitate organic anion efflux from plant roots. Plant Soil. 2003;248:61-9.

37. Piñeros MA, Magalhaes JV, Carvalho Alves VM, Kochian LV. The physiology and biophysics of an aluminum tolerance mechanism based on root citrate exudation in maize. Plant Physiol. 2002;129:1194-206.

38. Yu L, Yan J, Guo SR, Zhu WM. Aluminum-induced secretion of organic acid by cowpea (Vigna unguiculata L.) roots. Sci Hortic (Amsterdam). 2012;135:52-8.

39. Li XF, Zuo FH, Ling GZ, Li YY, Yu YX, Yang PQ, et al. Secretion of citrate from roots in response to aluminum and low phosphorus stresses in Stylosanthes. Plant Soil. 2009:325:219-29.

40. Yang LT, Jiang HX, Tang N, Chen LS. Mechanisms of aluminum-tolerance in two species of citrus: secretion of organic acid anions and immobilization of aluminum by phosphorus in roots. Plant Sci. 2011;180:521-30.
41. Collins NC, Shirley NJ, Saeed M, Pallotta M, Gustafson JP. An ALMT1 gene cluster controlling aluminum tolerance at the Alt4 locus of Rye (Secale cereale L.). Genetics. 2008;179:669-82.

42. Maron LG, Guimarães CT, Kirst M, Albert PS, Birchler JA, Bradbury PJ, et al. Aluminum tolerance in maize is associated with higher MATE1 gene copy number. Proc Natl Acad Sci U S A. 2013;110:5241-6.

43. Zhou GF, Delhaize E, Zhou MX, Ryan PR. The barley MATE gene, HvAACT1, increases citrate efflux and $\mathrm{Al}(3+)$ tolerance when expressed in wheat and barley. Ann Bot. 2013;112(3):603-12

44. Ma QB, Yi R, Li L, Liang ZY, Zeng TT, Zhang Y, et al. GsMATE encoding a multidrug and toxic compound extrusion transporter enhances aluminum tolerance in Arabidopsis thaliana. BMC Plant Biol. 2018;18(1):212.

45. Silva S, Pinto-Carnide O, Martins-Lopes P, Matos M, Guedes-Pinto H, Santos C. Differential aluminium changes on nutrient accumulation and root differentiation in an Al sensitive vs. tolerant wheat. Environ Exp Bot. 2010;68: 91-8

46. Tahara K, Hiradate S, Hashida K, Shinohara K. An aluminum-resistance mechanism in Eucalyptus camaldulensis: Complexation between aluminum and oenothein B in presence of organic acids in vitro. J For Res. 2017;22:261-4.

47. Wang HG, Zhang J, Yang WS, Wang XX, Cheng L. A comparative research on the allopathic of Eucalyputs grandis in different woodland. J Hebei Norm Univ (Nat Sci Ed). 2009;31(1):94-9.

48. Wang HG, Zhang J, Yang WS, Huang QM, Zou P. A research on the allelopathic substances in root system and roo t system soil of Eucalyptus grandis. J Sichuan Norm Univ (Nat Sci). 2006;29(3):368-71.

49. Bertin $\mathrm{C}$, Yang XH, Weston LA. The role of root exudates and allelochemicals in the rhizosphere. Plant Soil. 2003;256(1):67-83.

50. Ofei-Manu P, Wagatsuma T, Ishikawa S, Tawaraya K. The plasma membrane strength of the root-tip cells and root phenolic compounds are correiated with Al tolerance in several common woody plants. Soil Sci Plant Nutr. 2001:47:359-75.

51. Ma Z, Lin S. Transcriptomic revelation of phenolic compounds involved in aluminum toxicity responses in roots of Cunninghamia lanceolata (lamb.) hook. Genes (Basel). 2019. https://doi.org/10.3390/genes10110835.

52. Dong DF, Peng XX, Yan XL. Organic acid exudation induced by phosphorus deficiency and/or aluminium toxicity in two contrasting soybean genotypes Physiol Plant. 2004;122:190-9.

53. Li XF, Ma JF, Matsumoto H. Pattern of aluminum-induced secretion of organic acids differs between rye and wheat. Plant Physiol. 2000;123:1537-43.

54. Osawa H, Kojima K. Citrate-release-mediated aluminum resistance is coupled to the inducible expression of mitochondrial citrate synthase gene in Paraserianthes falcataria. Tree Physiol. 2006;26:565-74.

55. Xu MY, You JF, Hou NN, Zhang HM, Chen G, Yang ZM. Mitochondrial enzymes and citrate transporter contribute to the aluminium-induced citrate secretion from soybean (Glycine max) roots. Funct Plant Biol. 2010;37: 285-95.

56. Teng WC, Kang YH, Hou WJ, Hu HZ, Luo WJ, Wei J, et al. Phosphorus application reduces aluminum toxicity in two Eucalyptus clones by increasing its accumulation in roots and decreasing its content in leaves. PLoS One. 2018;13:1-20.

57. De La Fuente JM, Ramírez-Rodríguez V, Cabrera-Ponce JL, Herrera-Estrella L. Aluminum tolerance in transgenic plants by alteration of citrate synthesis. Science. 1997;276:1566-8.

58. Chen ZC, Liao H. Organic acid anions: an effective defensive weapon for plants against aluminum toxicity and phosphorus deficiency in acidic soils. J Genet Genomics. 2016;43(11):631-8.

59. Sharma T, Dreyer I, Kochian L, Piñeros MA. The ALMT family of organic acid transporters in plants and their involvement in detoxification and nutrient security. Front Plant Sci. 2016;7:1488.

60. Tesfaye M, Temple SJ, Allan DL, Vance CP, Samac DA. Overexpression of malate dehydrogenase in transgenic alfalfa enhances organic acid synthesis and confers tolerance to aluminum. Plant Physiol. 2001;127:1836-44.

61. Ryan PR, Tyerman SD, Sasaki T, Furuichi T, Yamamoto Y, Zhang WH, et al. The identification of aluminium-resistance genes provides opportunities for enhancing crop production on acid soils. J Exp Bot. 2011;62:9-20.

62. Wang Y, Xu H, Kou JJ, Shi L, Zhang CY, Xu FS. Dual effects of transgenic Brassica napus overexpressing CS gene on tolerances to aluminum toxicity and phosphorus deficiency. Plant Soil. 2013;362:231-46.

63. Wang P, Zhou R, Cheng JJ, Bi S. LC determination of trace short-chain organic acids in wheat root exudates under aluminum stress. Chromatographia. 2007;66:867-72. 
64. Dong XY, Shen RF, Chen RF, Zhu ZL, Ma JF. Secretion of malate and citrate from roots is related to high Al-resistance in Lespedeza bicolor. Plant Soil. 2008;306:139-47.

65. Chen LS, Tang N, Jiang HX, Yang LT, Li Q, Smith BR. Changes in organic acid metabolism differ between roots and leaves of Citrus grandis in response to phosphorus and aluminum interactions. J Plant Physiol. 2009; 166:2023-34.

66. Jenner HL, Winning BM, Millar AH, Tomlinson KL, Leaver CJ, Hill SA. NAD malic enzyme and the control of carbohydrate metabolism in potato tubers. Plant Physiol. 2001;126:1139-49.

\section{Publisher's Note}

Springer Nature remains neutral with regard to jurisdictional claims in published maps and institutional affiliations.

Ready to submit your research? Choose BMC and benefit from:

- fast, convenient online submission

- thorough peer review by experienced researchers in your field

- rapid publication on acceptance

- support for research data, including large and complex data types

- gold Open Access which fosters wider collaboration and increased citations

- maximum visibility for your research: over $100 \mathrm{M}$ website views per year

At BMC, research is always in progress.

Learn more biomedcentral.com/submissions 